\title{
Exploration on the Effective Integration of Craftsman Spirit and Curriculum Ideology and Politics Education
}

\author{
$\mathrm{Li} \mathrm{Li}^{*}{ }^{1}$, Sun Weiqi ${ }^{1}$, Zhou Bin ${ }^{1}$, Guo Feng ${ }^{1}$, Zhang Suqin ${ }^{1}$, Guo Xingxiang ${ }^{1}$, Li Kun ${ }^{1}$ \\ ${ }^{1}$ Naval Aviation University Qingdao Branch, Qingdao, China \\ *qdxqlixia@163.com
}

\begin{abstract}
The fundamental task of education is to cultivate morality and cultivate people. The ideological and political education of curriculum is a research hotspot in the current curriculum reform in China. Craftsman spirit is a kind of professional quality, its connotation includes dedication, lean, focus, innovation and so on. Craftsman spirit can improve the physical and mental quality of students, and can also make them have good professional ethics. This paper expounds the connotation of ideological and political education and craftsman spirit, points out the problems existing in the course teaching of colleges and universities, analyzes the problems concerned in the ideological and political education in colleges and universities, and probes into the effective integration of the cultivation of craftsman spirit and the ideological and political education of curriculum, and puts forward effective promotion strategies to realize the ideological and political education of professional courses by forming a great ideological and political pattern.
\end{abstract}

Keywords: curriculum ideological and politics, craftsman spirit, curriculum reform

\section{INTRODUCTION}

Infiltrating the ideological and political connotation in the course teaching is not only an important content of the reform and construction of higher education, but also the internal requirement for professional courses to achieve teaching objectives and talent cultivation objectives. The craftsman spirit is an important part of Chinese excellent cultural spirit, a spiritual magic weapon for national development and progress, a valuable resource for student education, a sacred duty and glorious mission for teachers under the background of vocational education, and an inevitable requirement for national development, national rejuvenation and student success. Therefore, to strengthen the cultivation of the craftsman spirit of the students can improve their moral quality and ideological morality, and realize the real cultivation of morality and cultivation of people for war. Teachers must adopt appropriate spiritual training methods, so that students' professional learning can be fully combined with professional needs, so as to cultivate the military talents needed by the society in the new era.

\section{THE MEANING OF IDEOLOGICAL AND POLITICAL EDUCATION AND CRAFTSMAN SPIRIT}

\subsection{Ideological and Political Education}

The ideological and political education of curriculum is to dig deeply into the ideological and political education elements contained in professional courses and general courses, and then effectively integrate the ideological and political education functions into the teaching of professional courses, so as to create a large ideological and political education teaching system of full staff education, whole process education and all-round education. Ideological and political education is an important method for schools to carry out ideological and political education for students and improve their ideological and political level ${ }^{[1]}$.

\subsection{Craftsman Spirit}

The essence of "craftsman spirit" is a kind of professional spirit, which is the concentrated embodiment of professional ethics, professional ability and professional character, and a kind of professional value orientation and behavior performance that practitioners 
should have. The connotation of craftsman spirit in the new era is the dedication, conscientious and responsible spirit of dedication, the spirit of meticulousness and excellence, the innovation spirit of diligent research and innovation, the practical spirit of paying attention to details and focusing on pragmatism, and the team spirit of unity and cooperation and making concerted efforts ${ }^{[2]}$.

\section{PROBLEMS EXISTING IN THE COURSE TEACHING OF COLLEGES AND UNIVERSITIES}

\subsection{The Trainees do not Understand the Craftsman Spirit}

The understanding degree of the craftsman spirit determines whether the craftsman spirit can influence or guide the practical behavior of the students. Most students know the word of craftsman spirit, but they do not understand its importance and rich connotation, and the relationship between craftsman spirit and professional quality.

\subsection{The Trainees do not have Craftsman Spirit}

Relevant departments have issued documents related to craftsman spirit, but on the whole, the learning atmosphere combined with craftsman spirit is not strong enough, many students lack craftsman spirit, especially reflected in the real learning life. In the teaching process, teachers should not only teach students professional knowledge, but also pay more attention to the cultivation of professional skills and how to improve professional quality. Therefore, it is imperative to explore a new mode of integrating craftsman spirit into classroom teaching.

\section{KEY ISSUES OF IDEOLOGICAL AND POLITICAL EDUCATION IN COLLEGES AND UNIVERSITIES ${ }^{[3-6]}$}

\subsection{The Spirit of Education must be in Line with the Times}

In the ideological and political education in colleges and universities, all disciplines must be innovated on the basis of the development of the times. Teachers should also make clear the development direction of education and the requirements of the times, so that the ideological and political education has strong pertinence and effectiveness. However, due to the lag of research on the development of the times in some colleges and universities, the practical application of ideological and political education has not been fully demonstrated. Therefore, it is difficult to cultivate students' good craftsman spirit in the course learning and practical teaching.

\subsection{Ideological and Political Education and Professional Learning must be Effectively Connected}

The new curriculum reform and quality education are repeatedly strong withered, in the teaching process, we need to give full play to the students' subjective initiative, so that their learning subject status can be fully displayed. At the same time, ideological and political education should be effectively combined with professional learning, fully tap the ideological and political elements, stimulate students to think actively, let students gradually develop the idea of excellence, serious and rigorous in the process of learning professional courses, and spare no effort to promote the better and faster development of this major.

\subsection{Ideological and Political Education and Career Development must be closely Linked}

Ideological and political education can promote the good development of quality education, so effective ideological and political education can improve the comprehensive quality of students, so that students can get personalized growth. Colleges and universities need to cultivate comprehensive applied talents for the society, so as to promote the continuous progress of society. Therefore, colleges and universities must pay attention to the training of students' practical operation, cultivate their patriotic consciousness, promote their personalized growth, ensure that they master qualified professional skills, have good professional ethics, and establish the spirit of dedication and persistence. In this way, after graduation, students will be able to have a seamless connection with their jobs and become a qualified talent.

The combination of craftsman spirit training and ideological and political education is not only the transmission of craftsman spirit, but also an important means to improve the ideological character of students. They are not isolated individuals. They can be perfectly integrated by using effective ways to guide students to establish correct professional spirit and comprehensively improve their comprehensive quality.

\section{STRATEGY RESEARCH ON THE INTEGRATION OF CRAFTSMAN SPIRIT AND CURRICULUM IDEOLOGY AND POLITICS}

\subsection{Concept first to Improve Teachers' Ideological and Political Literacy}

Teachers are the key to the ideological and political construction of course. We should consciously establish the educational concept of education as the foundation and moral education as the first, and put moral education in the first place of cultivating talents[7]. 
First of all, teachers should strengthen their own ideological and theoretical study, let them fully understand the connotation of ideological and political education through special research; at the same time, strengthen the communication and learning with ideological and political teachers, so that the ideological and political quality and level of professional teachers can be gradually improved. Secondly, teachers of professional courses should be clear about their moral responsibility, firmly establish the concept of education, and actively integrate ideological and political education into all aspects of curriculum teaching. Finally, teachers should actively reform the teaching content, flexibly use teaching methods, give full play to the enthusiasm, initiative and creativity, so that ideological and political education can be silent in the teaching of professional courses. Only by improving the teachers' ideological and political quality, can we grasp the connection between professional courses and ideological and political education, closely integrate the teaching objectives and moral education objectives ${ }^{[8]}$.

\subsection{Content Oriented, Mining Ideological and Political Elements of Professional Courses}

In the process of professional teaching, taking professional quality as the core and ability module as the main line, the integrated curriculum system of "teaching, learning and doing" is constructed. In order to cultivate students' post ability, the proportion of theoretical teaching and practical teaching is adjusted. In the process of teaching, the teacher injects craftsman spirit into the teaching content. At the same time, in the process of practical teaching, meticulous management is carried out, and skills training is emphasized, so as to cultivate and improve the vocational quality of students. In class, combined with the outstanding deeds of craftsmen from big countries, reform pioneers and moving China, the students can deeply understand and experience the craftsman spirit of persistence and concentration, rigorous style, excellence, dedication, persistence, and infiltrate the ideological and political quality, humanistic quality and professional quality into the teaching practice. the ideological and political integration points of the course are shown in Table 1.

Table 1 Integration Points of Ideological and Political Elements in the Course of 《Aviation Equipment Storage Management $\rangle$

\begin{tabular}{|l|l|}
\hline knowledge unit & $\begin{array}{c}\text { ideological and political points } \\
\text { of curriculum }\end{array}$ \\
\hline $\begin{array}{l}\text { warehouse } \\
\text { equipment } \\
\text { management }\end{array}$ & $\begin{array}{l}\text { watch the video of "craftsman } \\
\text { spirit" to carry out the education } \\
\text { of love and dedication for } \\
\text { students }\end{array}$ \\
\hline $\begin{array}{l}\text { aviation } \\
\text { equipment } \\
\text { packaging }\end{array}$ & $\begin{array}{l}\text { through the satellite } \\
\text { measurement and control } \\
\text { technology, the students are }\end{array}$ \\
\hline
\end{tabular}

\begin{tabular}{|c|c|}
\hline & educated for improvement \\
\hline $\begin{array}{l}\text { the time limit } \\
\text { management of } \\
\text { aviation } \\
\text { equipment }\end{array}$ & $\begin{array}{l}\text { through the example of Yuan } \\
\text { Longping to carry out the } \\
\text { education of struggle and } \\
\text { innovation for the students }\end{array}$ \\
\hline $\begin{array}{l}\text { warehouse } \\
\text { temperature and } \\
\text { humidity } \\
\text { management }\end{array}$ & $\begin{array}{l}\text { through the example of Chinese } \\
\text { women's volleyball team, to carry } \\
\text { out unity and cooperation } \\
\text { education for students }\end{array}$ \\
\hline
\end{tabular}

\subsection{Various Means to Reform Ideological and Political Teaching Methods}

The traditional teaching is relatively rigid, and the teaching results are very little. The development of the times, the innovation of technology and the change of the object have brought unprecedented impact to the ideological and political teaching, which has a profound impact on the form and effect of the ideological and political classroom teaching. We must innovate the ideological and political teaching according to the changes of the times and the characteristics of the students. To change the education methods and enrich the teaching forms, teachers should avoid the traditional cramming teaching method of "you tell me, I listen" in the teaching process, and actively adopt heuristic, question based, discussion based, project-based, task driven teaching methods to promote the deep interaction between teachers and students, and turn the cultivation of craftsman spirit of students into a conscious behavior habit, so as to greatly improve students' learning consciousness and initiative.

\subsection{Effect Test and Construction of Curriculum Assessment and Evaluation Mode}

According to the nature of the course, various assessment methods have been formulated, and the assessment system of theoretical teaching and practical teaching has been basically formed, which has promoted the teaching reform and the improvement of teaching quality. The assessment methods used in theory teaching are diversified, such as open book, closed book and written test. Practical teaching includes practical examination, practice report, etc. In order to refine the concept of craftsman spirit, the detailed assessment standards and methods are formulated, and the results are evaluated according to the usual performance, innovation ability, comprehensive design ability and other aspects, so as to reflect the professional skill level of students scientifically and truly. At the same time, problems can be found through students' feedback, teachers' selfevaluation and peer evaluation, so as to improve the teaching effect ${ }^{[9]}$.

\section{CONCLUSION}

Craftsman spirit is the soul of vocational education, and the teaching of professional courses is an important 
channel to cultivate craftsman talents. Ideological and political education in colleges and universities must fully show its value, not only to lead students to learn the basic theory, but also to strengthen the cultivation of students' quality. Therefore, the curriculum teaching should integrate the practical teaching concept, reform the curriculum teaching scheme, infiltrate the education of strengthening the army through science and technology, and cultivate the students' post ability, so that they have good craftsman spirit. Therefore, only by effectively integrating ideological and political elements into professional courses, giving full play to the role of moral education and cultivating talents, guiding students to set up correct three outlooks, walking in the same direction with ideological and political courses, and comprehensively improving students' ideological and political quality, can qualified new military talents be cultivated.

\section{FUND PROJECT}

Research project of Ideological and political education in Naval Aviation University in 2020 of "Research on the Integration System of Ideological and Political Education in the Course of Aviation Material Storage Management" (No.: HHCJ [2020] No. 606).

\section{REFERENCES}

[1] Wang fengxiao. Research on the Cultivation of Craftsman Spirit in Colleges and Universities under the Ideological and Political Concept of Curriculum [J]. Journal of Higher Education, 2019, (9): 148-150.

[2] Zhuang Qunhua. Cultivating Craftsman Spirit: what should be done and what can be done in Higher Vocational Colleges $[\mathrm{J}]$. Journal of Nanjing University of Aeronautics and Astronautics (SOCIAL SCIENCE EDITION), 2016, (3): 91-95.

[3] Cao Liping. Wang Jihui. On the Effective Integration of Craftsmanship Cultivation and Ideological and Political Education in Higher Vocational Colleges [J]. Journal of Jiamusi Vocational College, 2019 (6): 285-286.

[4] Yang Jinhui. Analysis on the Effective Integration of Craftsmanship Cultivation and Ideological and Political Education in Higher Vocational Colleges [J]. Textile Industry and Technology, 2019, 48 (6): 68-69.

[5] Li Wei. On the Effective Integration of Craftsman Spirit Cultivation and ideological and Political Education in Colleges and universities [J]. Think Tank Tra, 2019, (33): 82, 84.

[6] Zhou Juan. Analysis on the Effective Integration of Craftsman Spirit Cultivation and ideological and political education in Higher Vocational Colleges [J]. Think Tank Era, 2019, (25): 79, 81.

[7] Yan Lianfu, Wen Haixia. The Problems and Countermeasures of education in the Same Direction of Various Courses and Ideological and Political Courses in Colleges and Universities [J]. College Counselor, 2017, (08): 13-19.

[8] Ren Bowen, et al. Exploration on Ideological and political teaching of Engineering Training Center Courses from the Perspective of Craftsman Spirit: a Case Study of Fitter and Lathe Worker Courses in Nanjing University of Aeronautics and Astronautics [J]. Education Modernization, 2019,6 (61): 125 128136.

[9] Ye Qun, Chen Juan. Research on the Core Curriculum Reform of Electronic Specialty based on "Craftsman Spirit" [J]. Computer and Telecommunications, 2019, (z1): 50-51. 